Article

\title{
Importance of Gender, Location of Secondary School, and Professional Experience for GPA-A Survey of Students in a Free Tertiary Education Setting
}

\author{
Bartosz Kurek *(i) and Ireneusz Górowski \\ Department of Accounting, Institute of Management, College of Management and Quality Sciences, \\ Cracow University of Economics, ul. Rakowicka 27, 31-510 Cracow, Poland; gorowski@uek.krakow.pl \\ * Correspondence: kurekb@uek.krakow.pl; Tel.: +48-12-2935-529
}

Received: 7 October 2020; Accepted: 4 November 2020; Published: 6 November 2020

\begin{abstract}
A publicly financed tertiary education system is a manifestation of a sustainable approach to education. Society as a whole decides to spend money on the education of young generations, who in turn are expected to do the same for future generations. The benefactor expects that students conscientiously gain knowledge, skills, and competences during their studies. These features are incorporated into and measured with the grade point average (GPA). This research contributes to the scientific debate through the identification and measurement of determinants of students' GPA in a unique country setting, where top tertiary education is financed by a government. We investigate the relationship between GPA and differentiating factors: gender, population size of a town where students' secondary school was located, and professional experience. Research methods used include literature analysis, parametric and nonparametric statistical tests, and econometric modeling. The surveyed sample comprised 341 accounting and controlling students from Cracow University of Economics. We find that gender, location of a secondary school, and professional experience are statistically significantly associated with GPA. Female students tend to earn higher GPAs. Similarly, students who completed secondary education in smaller towns earn higher GPAs. On the contrary students who have professional experience tend to earn lower GPAs.
\end{abstract}

Keywords: GPA; tertiary education; gender; secondary school; professional experience

\section{Introduction}

When sustainability in its social and economic dimensions is considered, then education becomes a key issue [1]. Through developing and maintaining the system of education, young people are introduced to society and are prepared to give rise to the next generations. The educational system facilitates generational change and sustainable development of society. The tertiary education system is assumed to deliver new, competent human beings that are professionally (highly) qualified. In particular, by completing a university degree, young people gain special knowledge, unique skills, and competences that allow them to drive the economic and technological development of their countries. Moreover, university graduates contribute to the cultural development of societies. Last but not least, it is believed that holders of university degrees tend to receive higher salaries than blue-collar workers and therefore are more eager to subsidize universities (through alumni clubs).

In some countries, top research universities are public (e.g., Poland), whereas in other countries, top research universities are private (e.g., USA). A sustainable approach to education is clearly visible especially in the former countries. Society as a whole decides to spend money on education of young generations, who in turn are expected to do the same for future generations. Future graduates repay the debt by accumulating knowledge, gaining skills and competences during their education according 
to their intellectual potential, and then contributing their work to the development of civilization. It is therefore reasonable to believe that the benefactor (the society that finances tertiary education) expects that students conscientiously gain knowledge, skills, and competences during their studies. These features are incorporated into and measured with the grade point average (GPA).

As the literature suggests, GPA reflects the human capital acquisition of students [2] and correlates negatively with academic dishonesty [3]. Numerous studies report a positive significant relationship between college GPA and earnings [4-7]. Depending on the job, different qualifications of a candidate are relevant factors that employers consider when making decisions about whether to offer a position to a particular person. It seems reasonable to expect that another important factor is GPA, as it is a valid predictor of job performance [8]. Therefore, as Oehrlein [9] (p. 28) notes, "employers often use GPA as part of the screening process for employees." We believe that students are economically motivated and therefore maximize their chances in the labor market by maximizing their GPA and gaining professional experience and additional relevant qualifications (though it may not be possible to succeed in all three attributes at the same time).

Gender is an important differentiating success factor in education. Current literature proves that girls are better adapted to today's school environment [10]. Starting in elementary, middle, and high school, female pupils earn higher grades than male pupils in all major subjects $[11,12]$. The very suggestive title "At colleges, women are leaving men in the dust" [13] evidently illustrates significantly better achievements of females during studies. The study by Bridgeman and Wendler [14] shows that within a given college mathematics course, the average grades of women were about equal to or slightly higher than men's average grades, but men's average scores on the mathematical scale of the Scholastic Assessment Test (SAT, taken when applying to college) were above women's average scores by a third of a standard deviation or more. This research suggests that women accelerate their knowledge and skills during their studies. Conger and Long [15] associate lower GPAs of male students in the first semester of college with lower high school grades.

College GPA can also be adversely affected by starting a professional career too early (during studies). It can distract students from learning and create a deficit in achieving the intended learning outcomes and GPA. Research on students in different countries has shown a slight but essential negative effect of employment on student achievement [16,17] and that working students are less satisfied with their studies [18]. The research on work-study conflict also reveals a negative impact of employment during studies on academic engagement and achievement in various countries [19-21]. It is also reported that there is a working hours threshold beyond which there is a negative effect on GPA [22]. However, research showing positive effects of students' employment (part-time) during studies also exists [23,24]. Some researchers [25] argue that there is no difference in grades between employed and non-employed students, but at the same time notice that employed students could have scored better if they had not worked. Researchers [26] also demonstrate that students with busy schedules exhibit high self-regulation and assign priorities to their goals. Furthermore, it is suggested that students value an increase in GPA differently and choose their activities accordingly [27]. Thus, the results of previous research can be considered inconsistent.

At the same time, students notice the need to gain professional experience during their studies. There are many reasons for taking up work while being a student-earning money to cover essentials or related expenses; relieving the financial burden of parents; expanding their network with managers, employees, and customers; gaining work experience or practical skills; supporting a particular lifestyle; or as a reaction to peer influence and socializing and meeting people [18].

This paper aims to investigate selected determinants of GPA among accounting and controlling students. The outcome of the research might be valuable to policymakers and university administrations in stimulating a sustainable approach to education. The conclusions are limited to countries in which tertiary education is financed with public monies. 
We contribute to the scientific debate by identifying determinants of GPA for accounting and controlling students in a unique country setting, where top tertiary education is financed by the government.

The pillar of the Polish system of higher education is built on publicly funded universities. Most spending on higher education in Poland comes from the state. Full-time undergraduate and graduate studies are free for Polish citizens. According to the Organization for Economic Cooperation and Development (OECD), public spending on higher education in 2015 constituted $79.1 \%$ of total spending on higher education [28], which equaled $1.1 \%$ of Poland's gross domestic product (GDP). In Poland, about three-quarters of the tertiary students at the bachelor's level attend public institutions [29]. The Polish state also directly subsidizes public universities and students through scholarships and various forms of social assistance and, to a lesser extent, also supports private universities (e.g., by providing research grants and scholarships to students). In the economic sense, all taxpayers (i.e., society) finance the higher education system.

In this unique setting, accounting studies are highly feminized [30,31] and highly desired in Poland. It is not surprising that one particular field of study in Poland is usually chosen by one gender, as in Poland generally there is no gender parity at the tertiary educational level. Wieczorek-Szymańska [32] reports that the most popular fields of graduation for women in Poland include business, administration, and law (highly feminized accounting is a part of the business field). Interestingly, according to the OECD [29], gender parity among tertiary fields of study is only reached in business, administration, and law, with 57\% women. According to information from the Ministry of Science and Higher Education [33], the number of candidates for accounting studies is quite high: Accounting and Controlling-5.7, Accounting and Business Finance-4.2, and Financial Management and Accounting-4.1. However, the number of candidates still is relatively low if it is compared to the number of candidates for the most desired major, which is Oriental and Japanese Studies-26.1, and for the second most desired major, which is Mathematics and Data Analysis-22.2. Zarzycka and Dobroszek [34] report that the educational offer in the field of accounting and finance in Poland is extensive, including Association of Chartered Certified Accountants (ACCA) and Chartered Institute of Management Accountants (CIMA) qualifications. The reason for such popularity is probably the current labor market situation, which shows a deficit of employees in Poland (including Lesser Poland voivodeship) in the area of accounting and bookkeeping [35].

Students are part of the social structure of the country and come from different backgrounds. In Poland, the problem of social exclusion of people from small cities is often discussed, also when education is concerned. Świerzbowska-Kowalik's [36] analysis shows that the chances of starting university studies by youth from the countryside are almost twice as low as for young people living permanently in cities.

Complex research in the area of gaining professional experience during studies is lacking for Poland. The current state of knowledge in this field allows us to assume that the main reason for students to seek work is to earn additional money [37]. We believe that students' motivations in Poland do not differ from students' motivations in other countries.

We measure and explain the relationship between GPA and gender, location of secondary school, professional experience, study form (full time/part time), educational level (bachelor's/master's), additional professional qualifications, and foreign language certificates. We find that gender, location of secondary school, professional experience, study form, and educational level are significantly associated with GPA. Male students and students who have professional experience tend to earn lower GPAs. On the contrary, full-time students, master's students, and students who completed secondary education in a town with less than 100,000 inhabitants tend to earn higher GPAs. All results, except for the coefficient next to location of secondary school variable, seem to have the expected sign. It is puzzling that students who completed secondary education in a town with less than 100,000 inhabitants tend to earn higher GPAs than other students. One of the plausible explanations for this phenomenon 
is that these students study harder than other students as they see their academic performance as the key to the successful career in a metropolis (in Poland biggest universities are located in large cities).

The research methods used in this paper include: (1) literature review, (2) statistical tests (the Shapiro-Wilk W test was used to test normality, the two-sample $t$ test with unequal variances was used to verify statistical difference between means, the two-sample Wilcoxon rank sum/Mann-Whitney test was used to verify statistical difference between medians, Pearson's chi-square test was used to measure association, and the Spearman rank correlation was used to test correlation between variables), (3) econometric modeling (regression analysis: linear models estimated by ordinary least squares with Huber/White robust standard errors). The following software was used: Stata/IC 14.1 for statistical tests and econometric modeling and Microsoft Office Excel 2013 for initial data filtering and descriptive statistics.

The paper is organized as follows: In Section 1 we introduce the research problem and review relevant literature, in Section 2 we develop research hypotheses, in Section 3 we operationalize research hypotheses and develop econometric models, in Section 4 we describe the data, in Section 5 we analyze regression results, and in Section 6 we conclude and signal the limitations of the study and highlight some possibilities for further studies. A list of references follows the last section.

\section{Hypotheses Development}

Previous research findings confirm that women are successful students and accomplish better educational results than male students. We are verifying whether these results hold in a unique setting of Poland among a group of accounting and controlling students at Cracow University of Economics. It is expected that female students obtain greater GPAs than male students and that the difference is statistically significant.

Research Hypothesis 1 (H1). Female accounting and controlling students earn higher GPAs.

Inequality in access to education is often linked to the country of origin. Within a particular country it is further associated with the city of origin (larger cities-better chances, smaller cities and villages-lower chances). It is reasonable to claim that top-rated secondary schools are located in larger cities [38]. Additionally, larger cities offer more extracurricular activities for youngsters. On the other hand, common access to the Internet should limit these disproportions. Some students from smaller cities and villages may still treat studies at a university in a large city as a form of social advancement. These students may feel that a higher GPA is associated with better chances in the labor market.

Research Hypothesis 2 (H2). Accounting and controlling students who come from small towns earn lower GPAs.

The trade-off between education and work and its implication for students has been the subject of numerous research papers. Students face a tough decision, as it is a one-off decision with serious implications for future graduates. Employment during studies may act to the advantage and to the detriment of students at the same time (gaining professional experience and spending less time on studies and thus achieving worse results in courses). A society that finances studies may expect that students will gain knowledge and acquire skills and competences that will be used for the benefit of this society. These features are incorporated into and measured through GPA. It is therefore valuable to empirically verify in a unique setting whether there is an association between undertaking work and GPA. The statistically significant negative relationship (employment-lower GPA) should further stimulate more precise research in determining the causal relationship between time spent on work and the decrease in GPA. In the case of publicly financed higher education, policymakers and society have the right to demand from students a complete devotion to gaining knowledge, skills, and competences. 
Research Hypothesis 3 (H3). Accounting and controlling students who have professional experience earn lower GPAs.

\section{Operationalization of Research Hypotheses}

According to the research hypotheses, students' performance is related to gender, location of secondary school, and professional experience. It is reasonable to believe that academic performance is related to study form, educational level, and other educational activities that students undertake during their studies.

To empirically verify the general research hypothesis, we set out five econometric models. In three models (no. 1-3), there is only one independent variable: gender (male/female), location of secondary school (small town/other town), or professional experience (experience/no experience). In one model (no. 4), these three independent variables are combined. In one model (no. 5) we combine these three independent variables but we also control for study form (full time/part time) and educational level (bachelor's/master's), and in one model (no. 6) we further control for additional professional qualifications and foreign language certificates. Variables are defined in Table 1.

Table 1. Definitions of variables.

\begin{tabular}{|c|c|c|}
\hline Variable & Expected Sign & Description \\
\hline GPA & $x$ & $\begin{array}{l}\text { Grade point average. GPA is the arithmetic average of all grades } \\
\text { from the previous academic year. At Cracow University of } \\
\text { Economics, the following grading system scale is in force: one } \\
\text { failing grade (2.0) and six passing grades }(3.0,3.5,4.0,4.5,5.0,5.5) \text {. } \\
\text { For example, a student took six courses in the previous academic } \\
\text { year and received the following grades: } 3.0,3.5,4.0,4.5,5.0,5.0 \text {. } \\
\text { Therefore the GPA would equal ( } 3.0+3.5+4.0+4.5+5.0+5.0) / 6= \\
4.17 \text { (rounded according to mathematical rules). At Cracow } \\
\text { University of Economics, each course has the same weight. If a } \\
\text { student receives a failing grade, he/she has to retake the course and } \\
\text { eventually has to receive a passing grade in order to graduate. }\end{array}$ \\
\hline Gender & - & Dichotomous variable (1—male, 0 -female) \\
\hline Small Town & - & $\begin{array}{l}\text { Dichotomous variable ( } 1 \text {-student completed secondary education } \\
\text { in a town with less than } 100,000 \text { inhabitants, } 0 \text { - student completed } \\
\text { secondary education in a town with } 100,000 \text { inhabitants or more) }\end{array}$ \\
\hline Experience & - & $\begin{array}{l}\text { Dichotomous variable (1—student has professional experience, } \\
0 \text {-student does not have any professional experience) }\end{array}$ \\
\hline Full Time & + & $\begin{array}{l}\text { Dichotomous variable (1—student studies full time, } 0 \text { —student } \\
\text { studies part time }\end{array}$ \\
\hline Master's & + & $\begin{array}{l}\text { Dichotomous variable (1—student studies in a master's program, } \\
0 \text {-student studies in a bachelor's program) }\end{array}$ \\
\hline Prof Qual & + & $\begin{array}{l}\text { Dichotomous variable ( } 1 \text {-student participated in non-free trainings } \\
\text { that improved his/her professional qualifications in the area of } \\
\text { accounting, controlling, and finance, } 0 \text { - student did not participate } \\
\text { in non-free trainings that improved his/her professional } \\
\text { qualifications in the area of accounting, controlling, and finance) }\end{array}$ \\
\hline Lang Cert & + & $\begin{array}{l}\text { Dichotomous variable (1-student has a foreign language certificate, } \\
0 \text {-student does not have a foreign language certificate). Examples } \\
\text { of foreign language certificates include: First Certificate in English } \\
\text { (FCE), Certificate in Advanced English (CAE), Certificate of } \\
\text { Proficiency in English (CPE), and Test of English as a Foreign } \\
\text { Language (TOEFL). }\end{array}$ \\
\hline
\end{tabular}

Econometric models are presented in Table 2. 
Table 2. Econometric models.

\begin{tabular}{cl}
\hline No. & \multicolumn{1}{c}{ Specification } \\
\hline 1 & GPA $=\beta_{0}+\beta_{1}$ Gender $+\varepsilon$ \\
\hline 2 & GPA $=\beta_{0}+\beta_{2}$ Small Town $+\varepsilon$ \\
\hline 3 & GPA $=\beta_{0}+\beta_{3}$ Experience $+\varepsilon$ \\
\hline 4 & GPA $=\beta_{0}+\beta_{1}$ Gender $+\beta_{2}$ Small Town $+\beta_{3}$ Experience $+\varepsilon$ \\
\hline 5 & GPA $=\beta_{0}+\beta_{1}$ Gender $+\beta_{2}$ Small Town $+\beta_{3}$ Experience $+\beta_{4}$ Full Time $+\beta_{5}$ Master's $+\varepsilon$ \\
\hline 6 & $\begin{array}{l}\text { GPA }=\beta_{0}+\beta_{1} \text { Gender }+\beta_{2} \text { Small Town }+\beta_{3} \text { Experience }+\beta_{4} \text { Full Time }+\beta_{5} \text { Master's } \\
+\beta_{6} \text { Prof Qual }+\beta_{7} \text { Lang Cert }+\varepsilon\end{array}$ \\
\hline
\end{tabular}

The expected sign for Gender is minus, as according to literature male students generally earn lower GPAs than female students.

The expected sign for Small Town is minus, as we believe that in larger cities, students probably have easier access to additional educational services and the possibility of closer contact with the academic community. We therefore conclude that top secondary schools prepare their pupils for studies in a better way.

The expected sign for Experience is minus, as students who work are less focused on studying. Moreover, we are convinced that success in studying does not correspond to gaining professional experience.

We also believe that full-time students have more time for studying and more in-class hours for every subject compared to part-time students. Therefore, the expected sign for Full Time is plus.

The expected sign for Master's is plus. It is reasonable to believe that graduate students are more matured than undergraduate students. As a result, graduate students value GPA more and therefore are more hardworking than their younger colleagues.

The expected sign for Prof Qual (professional qualifications) is plus, as we believe that participants of non-free trainings in the area of accounting, controlling, and finance have a better understanding of concepts that are covered during university courses. Furthermore, we believe that if a student pays for a particular training, he/she is more motivated to gain knowledge and skills in the trained area. Therefore, such students should score better than their peers who did not participate in non-free trainings.

Similarly, we believe that holders of foreign language certificates should score better than other students (at least in language courses). Therefore, the expected sign for Lang Cert (language certificate) is plus.

\section{Data Description and Initial Analysis}

Cracow is the biggest business processing outsourcing (BPO) center in Poland [39]. In 2019, Cracow took 11th place in the world and second in Europe, after Dublin, in the Tholons Services Globalization Index ranking [40], which shows the city's importance in the market of modern business services and indicates further development prospects in this respect. An important part of this market is constituted by BPO centers offering various services in the field of different financial processes. That is why accounting and controlling students are sought after by such outsourcing centers, which offer them flexible conditions and attractive salaries. Many graduates continue to work for these companies. As Łada and Konieczny [41] report, employees of BPO centers treat their employment as an opportunity to gain experience in an international environment.

The survey was conducted in the first two weeks of October 2019 among accounting and controlling students from Cracow University of Economics. More specifically, second- and third-year bachelor's students and first- and second-year master's students are included in the analysis, as only these students can provide GPAs from the previous academic year. According to data provided by Cracow University of Economics, the total number of accounting and controlling students (all years of bachelor's and 
master's studies) as of 1 October, 2019 equaled 1432, including 217 students enrolled in the first year of bachelor's studies. Therefore, the size of the population equals 1215 (1432 - 217). In total, 498 questionnaires were distributed among second- and third-year bachelor's students and first- and second-year master's students who were present at lectures. However, in the case of some courses, participation in lectures might not be obligatory, which is the main reason for not covering all of the students in the analysis. There were 341 questionnaires that contained all the information that was required for this research. Therefore, the completion rate is at the level of $68.47 \%$ (341/498), which covers $28.07 \%$ of the whole population (341/1215) and $23.81 \%(341 / 1432)$ of the whole number of accounting and controlling students at Cracow University of Economics.

Table 3 presents descriptive statistics (minimum, maximum, average, standard deviation, coefficient of variation, first quartile-Q1, median, third quartile-Q3, skewness, kurtosis, number of observations $-\mathrm{n}$ ) for each of the variables in the analyzed sample. In the analyzed sample GPA ranged from 3.40 to 5.17. The mean GPA equaled 4.35 and the median equaled 4.32 , both of which seem to be relatively high.

Table 3. Descriptive statistics of variables.

\begin{tabular}{ccccccccc}
\hline Variable & GPA & Gender & $\begin{array}{c}\text { Small } \\
\text { Town }\end{array}$ & Experience & $\begin{array}{c}\text { Full } \\
\text { Time }\end{array}$ & Master's & $\begin{array}{c}\text { Prof } \\
\text { Qual }\end{array}$ & $\begin{array}{c}\text { Lang } \\
\text { Cert }\end{array}$ \\
\hline Minimum & 3.40 & 0.00 & 0.00 & 0.00 & 0.00 & 0.00 & 0.00 & 0.00 \\
\hline Maximum & 5.17 & 1.00 & 1.00 & 1.00 & 1.00 & 1.00 & 1.00 & 1.00 \\
\hline Average & 4.35 & 0.18 & 0.62 & 0.88 & 0.62 & 0.49 & 0.13 & 0.12 \\
\hline $\begin{array}{c}\text { Standard } \\
\text { deviation }\end{array}$ & 0.37 & 0.39 & 0.48 & 0.33 & 0.48 & 0.50 & 0.34 & 0.33 \\
\hline $\begin{array}{c}\text { Coefficient of } \\
\text { variation }\end{array}$ & 0.09 & 2.10 & 0.78 & 0.37 & 0.78 & 1.02 & 2.53 & 2.67 \\
\hline Q1 & 4.09 & 0.00 & 0.00 & 1.00 & 0.00 & 0.00 & 0.00 & 0.00 \\
\hline Median & 4.32 & 0.00 & 1.00 & 1.00 & 1.00 & 0.00 & 0.00 & 0.00 \\
\hline Q3 & 4.60 & 0.00 & 1.00 & 1.00 & 1.00 & 1.00 & 0.00 & 0.00 \\
\hline Skewness & -0.03 & 1.63 & -0.52 & -2.35 & -0.50 & 0.04 & 2.15 & 2.30 \\
\hline Kurtosis & -0.51 & 0.67 & -1.74 & 3.52 & -1.76 & -2.01 & 2.62 & 3.33 \\
\hline $\mathrm{n}$ & 341 & 341 & 341 & 341 & 341 & 341 & 341 & 341 \\
\hline
\end{tabular}

In the analyzed sample $82 \%$ of students were female, $62 \%$ completed secondary education in a small town with less than 100,000 inhabitants, $88 \%$ had professional experience, $51 \%$ studied at the bachelor's level, $62 \%$ studied full time, $87 \%$ did not participate in non-free trainings that could improve professional qualifications in the area of accounting, controlling and finance, and $88 \%$ did not hold any foreign language certificates.

The normality tests for GPA do not reject the assumption of normality of data at a $5 \%$ significance level. The Shapiro-Wilk W test was used to test the normality of the data (H0: a sample comes from a normally distributed population, H1: a sample does not come from a normally distributed population). The whole sample and subsamples were tested. Subsamples were generated by applying classifications based on all independent variables: Gender, Small Town, Experience, Full Time, Master's, Prof Qual, Lang Cert (e.g., if a grouping variable was Gender, then the first GPA subsample consisted of females and the second GPA subsample consisted of males). However, it is worth noting that some of the test $p$-values were below 0.10: Gender-female subgroup 0.05030, Prof Qual—no qualification subgroup 0.06485, Full Time-full-time subgroup 0.06646, Master's—master's program subgroup 0.07488.

In the subsequent analysis we conducted tests of the difference between means and tests of the difference between medians for GPA subsamples. The two-sample $t$ test with unequal variances was used to verify the statistical difference between means (H0: means are equal, $\mathrm{H} 1$ : means are not equal). The two-sample Wilcoxon rank sum (Mann-Whitney) test was used to verify the statistical difference 
between medians (H0: two independent samples are from populations with the same distribution, $\mathrm{H} 1$ : two independent samples are not from populations with the same distribution). We used both the parametric test (the former one) due to the normality assumption and the non-parametric test (the latter one) for robustness analysis. Similarly to the normality tests, GPA subsamples were generated by applying classifications based on all independent variables: Gender, Small Town, Experience, Full Time, Master's, Prof Qual, Lang Cert (e.g., if a grouping variable was Gender, then the first GPA subsample consisted of females and the second GPA subsample consisted of males). There are statistically significant (at 5\%) differences between means and statistically significant (at 5\%) differences between medians for five grouping variables: Gender, Small Town, Experience, Full Time and Master's. The average GPA of females equals 4.38 and is greater by 0.17 ( $p$-value $=0.0008)$. The median GPA of females also equals 4.38 and is greater by 0.18 ( $p$-value $=0.0019)$. The average GPA of students who completed secondary education in a town with less than 100,000 inhabitants equals 4.38 and is greater by 0.09 ( $p$-value $=0.0360$ ). The average GPA of students who did not have any professional experience equals 4.46 and is greater by 0.14 ( $p$-value $=0.0204$ ). The average GPA of full-time students equals 4.44 and is greater by 0.26 ( $p$-value $<0.0001)$. The average GPA of master's students equals 4.48 and is greater by 0.26 ( $p$-value $<0.0001)$. There are no statistically significant differences between means and medians for two grouping variables: Prof Qual and Lang Cert.

In addition, the association between GPA and each of the independent variables (Gender, Small Town, Experience, Full Time, Master's, Prof Qual, Lang Cert) was measured. Pearson's chi-square test was used to test association (H0: two categorical variables are independent in a population, $\mathrm{H} 1$ : two categorical variables are not independent in a population; the number of degrees of freedom equals 1 ). For every variable we examined whether there was a statistical difference in the frequency of achieving higher/lower GPA than the median GPA of 4.32 (e.g., if the grouping variable was Gender, then the first GPA subsample consisted of females and the second GPA subsample consisted of males). We found that some groups of students tend to earn GPAs above the median GPA: female students ( $p$-value $=0.074$ ), full-time students ( $p$-value $<0.001$ ), and master's students ( $p$-value $<0.001)$, as well as students who completed secondary education in a small town with less than 100,000 inhabitants ( $p$-value $=0.028$ ), students without professional experience $(p$-value $=0.064)$, and students who participated in non-free trainings that improved his/her professional qualifications in the area of accounting, controlling, and finance $(p$-value $=0.025)$.

\section{Analysis of Regression Results}

In this section we verify six econometric models that were outlined in Table 2. In Table 4 we present Spearman rank correlation coefficients between variables accompanied by their statistical significance levels. All independent variables except for Prof Qual and Lang Cert are correlated with GPA, and the correlations are highly statistically significant. Gender, as expected, is not significantly correlated with any other independent variable. Similarly, Small Town is not significantly correlated with any other independent variable except for Lang Cert. The correlation is negative, and the reason for that might be low availability of language schools that prepare for foreign language exams in small towns. Experience is significantly negatively correlated with Full Time-students who study full time may have less time for getting professional experience (although an internship is an obligatory part of studies). Master's is significantly positively correlated with Full Time, Prof Qual, and Lang Cert. Graduate students are older than undergraduate students and probably had more opportunities to participate in non-free trainings in the area of accounting, controlling, and finance, as well as had more time to gain foreign language certificates. 
Table 4. Spearman rank correlation coefficients " $\rho$ ".

\begin{tabular}{|c|c|c|c|c|c|c|c|c|}
\hline & GPA & Gender & Small Town & Experience & Full Time & Master's & Prof Qual & Lang Cert \\
\hline GPA & 1 & & & & & & & \\
\hline Gender & $\begin{array}{c}\rho=-\mathbf{0 . 6 8 5} \\
0.0018\end{array}$ & 1 & & & & & & \\
\hline Small Town & $\begin{array}{c}\rho=0.1087^{* *} \\
0.0449\end{array}$ & $\begin{array}{c}\rho=0.0101 \\
0.8524\end{array}$ & 1 & & & & & \\
\hline Experience & $\rho=\frac{-0.1162}{0.0320}$ *** & $\begin{array}{c}\rho=0.0134 \\
0.8059\end{array}$ & $\begin{array}{c}\rho=-0.0445 \\
0.4127\end{array}$ & 1 & & & & \\
\hline Full Time & $\begin{array}{c}\rho=0.3461^{* * *} \\
<0.0001\end{array}$ & $\begin{array}{c}\rho=0.0130 \\
0.8113\end{array}$ & $\begin{array}{c}\rho=0.0572 \\
0.2925\end{array}$ & $\begin{array}{c}\rho=-\mathbf{0 . 2 1 4 0} \\
0.0001\end{array}$ & 1 & & & \\
\hline Master's & $\begin{array}{c}\rho=0.3403^{* * * *} \\
<0.0001\end{array}$ & $\begin{array}{c}\rho=-0.0431 \\
0.4273\end{array}$ & $\begin{array}{c}\rho=0.0447 \\
0.4110\end{array}$ & $\begin{array}{c}\rho=0.0555 \\
0.3065\end{array}$ & $\begin{array}{c}\rho=0.2199 \\
<0.0001\end{array}$ & 1 & & \\
\hline Prof Qual & $\begin{array}{c}\rho=0.0801 \\
0.1398\end{array}$ & $\begin{array}{c}\rho=0.0775 \\
0.1536\end{array}$ & $\begin{array}{c}\rho=-0.0130 \\
0.8110\end{array}$ & $\begin{array}{c}\rho=0.0668 \\
0.2186\end{array}$ & $\begin{array}{c}\rho=-0.0637 \\
0.2408\end{array}$ & $\begin{array}{c}\rho=0.1455^{* * *} \\
0.0071\end{array}$ & 1 & \\
\hline Lang Cert & $\begin{array}{c}\rho=0.0147 \\
0.7868\end{array}$ & $\begin{array}{c}\rho=0.0285 \\
0.5997\end{array}$ & $\begin{array}{c}\rho=-\mathbf{0 . 1 3 3 3} \\
0.0137\end{array}$ & $\begin{array}{c}\rho=0.0837 \\
0.1230\end{array}$ & $\begin{array}{c}\rho=0.0532 \\
0.3278\end{array}$ & $\begin{array}{c}\rho=\mathbf{0 . 0 9 7 0} * \\
0.0738\end{array}$ & $\begin{array}{c}\rho=0.0349 \\
0.5212\end{array}$ & 1 \\
\hline
\end{tabular}

Notes: The first number represents Spearman rank correlation coefficient " $\rho$ ", which is bolded if the correlation is statistically significant ${ }^{*}$ statistically significant at $10 \%$, ${ }^{* *}$ statistically significant at $5 \%,{ }^{* * *}$ statistically significant at $1 \%$ ). The second number represents the $p$-value. 
Table 5 presents the regression results. All models are linear and all of them were estimated by ordinary least squares (OLS). Huber/White robust standard errors were used to assess statistical significance of each parameter. In all models Gender is statistically significant at the $1 \%$ level. Holding all other variables fixed, the predicted difference in GPA between male and female students is about -0.17 (model 6). Similarly, in all models Small Town and Experience are statistically significant at the $10 \%$ level. Holding all other variables fixed, the predicted difference in GPA between a student who completed secondary education in a small town with less than 100,000 inhabitants and a student who completed secondary education in a bigger town is about +0.07 (model 6). Holding all other variables fixed, the predicted difference in GPA between a student who had professional experience and a student who did not have any professional experience is -0.09 (model 6). Full Time and Master's are both individually statistically significant at the $1 \%$ level. Holding all other variables fixed, the predicted difference in GPA between a full-time and part-time student is about +0.21 . Holding all other variables fixed, the predicted difference in GPA between a master's and bachelor's student is about +0.20. Prof Qual and Lang Cert have no effect on GPA once Gender, Small Town, Experience, Full Time, and Master's are accounted for (model 6). 
Table 5. Econometric models-results of estimation

\begin{tabular}{|c|c|c|c|c|c|c|}
\hline Model & Model 1 & Model 2 & Model 3 & Model 4 & Model 5 & Model 6 \\
\hline Variables & \multicolumn{6}{|c|}{ Dependent variable: GPA } \\
\hline $\begin{array}{l}\text { Independent variable } \\
\text { Gender }\end{array}$ & $\begin{array}{c}-\mathbf{0 . 1 7} \mathbf{1}^{* * *} \\
(0.05) \\
p \text {-value }=0.0006\end{array}$ & & & $\begin{array}{c}-\mathbf{0 . 1 7} \\
(0.05) \\
p \text {-value }=0.0004\end{array}$ & $\begin{array}{c}-\mathbf{- 0 . 1 6} \mathbf{~}^{\text {*** }} \\
(0.05) \\
p \text {-value }=0.0005\end{array}$ & $\begin{array}{c}-\mathbf{0 . 1 7} \\
(0.05) \\
p \text {-value }=0.0003\end{array}$ \\
\hline $\begin{array}{l}\text { Independent variable } \\
\text { Small Town }\end{array}$ & & $\begin{array}{c}\mathbf{0 . 0 9} * * \\
(0.04) \\
p \text {-value }=0.0356\end{array}$ & & $\begin{array}{c}\mathbf{0 . 0 9} * * \\
(0.04) \\
p \text {-value }=0.0363\end{array}$ & $\begin{array}{c}\mathbf{0 . 0 7}{ }^{*} \\
(0.04) \\
p \text {-value }=0.0766\end{array}$ & $\begin{array}{c}\mathbf{0 . 0 7}{ }^{*} \\
(0.04) \\
p \text {-value }=0.0801\end{array}$ \\
\hline $\begin{array}{l}\text { Independent variable } \\
\text { Experience }\end{array}$ & & & $\begin{array}{c}-\mathbf{0 . 1 4} \mathbf{4}^{* *} \\
(0.06) \\
p \text {-value }=0.0166\end{array}$ & $\begin{array}{c}-\mathbf{0 . 1 3} * * \\
(0.06) \\
p \text {-value }=0.0250\end{array}$ & $\begin{array}{c}\mathbf{- 0 . 0 8}^{*} \\
(0.05) \\
p \text {-value }=0.0978\end{array}$ & $\begin{array}{c}-\mathbf{- 0 . 0 9}^{*} \\
(0.05) \\
p \text {-value }=0.0855\end{array}$ \\
\hline $\begin{array}{l}\text { Independent variable } \\
\text { Full Time }\end{array}$ & & & & & $\begin{array}{c}\mathbf{0 . 2 0} * * * \\
(0.04) \\
p \text {-value }<0.0001\end{array}$ & $\begin{array}{c}\mathbf{0 . 2 1} \text { *** } \\
(0.04) \\
p \text {-value }<0.0001\end{array}$ \\
\hline $\begin{array}{l}\text { Independent variable } \\
\text { Master's }\end{array}$ & & & & & $\begin{array}{c}\mathbf{0 . 2 1}{ }^{* * *} \\
(0.04) \\
p \text {-value }<0.0001\end{array}$ & $\begin{array}{c}\mathbf{0 . 2 0}{ }^{* * *} \\
(0.04) \\
p \text {-value }<0.0001\end{array}$ \\
\hline $\begin{array}{l}\text { Independent variable } \\
\text { Prof Qual }\end{array}$ & & & & & & $\begin{array}{c}0.08 \\
(0.06) \\
p \text {-value }=0.1581\end{array}$ \\
\hline $\begin{array}{l}\text { Independent variable } \\
\text { Lang Cert }\end{array}$ & & & & & & $\begin{array}{c}-0.01 \\
(0.06) \\
p \text {-value }=0.8810\end{array}$ \\
\hline Constant & $\begin{array}{c}4.38^{* * *} \\
(0.02) \\
p \text {-value }<0.0001\end{array}$ & $\begin{array}{c}4.29 * * * \\
(0.04) \\
p \text {-value }<0.0001\end{array}$ & $\begin{array}{c}4.46^{* * *} \\
(0.05) \\
p \text {-value }<0.0001\end{array}$ & $\begin{array}{c}4.43^{* * *} \\
(0.06) \\
p \text {-value }<0.0001\end{array}$ & $\begin{array}{c}4.18^{* * *} \\
(0.06) \\
p \text {-value }<0.0001\end{array}$ & $\begin{array}{c}4.17^{* * *} \\
(0.06) \\
p \text {-value }<0.0001\end{array}$ \\
\hline $\mathrm{n}$ & 341 & 341 & 341 & 341 & 341 & 341 \\
\hline $\mathrm{R}^{2}$ & 0.0319 & 0.0137 & 0.0143 & 0.0586 & 0.2372 & 0.2423 \\
\hline $\mathrm{F}$ & $\begin{array}{c}\mathrm{F}(1339)=12.09 * * * \\
p \text {-value }=0.0006\end{array}$ & $\begin{array}{l}\mathrm{F}(1339)=4.45^{* *} \\
p \text {-value }=0.0356\end{array}$ & $\begin{array}{l}\mathrm{F}(1339)=5.79 * * \\
p \text {-value }=0.0166\end{array}$ & $\begin{array}{l}\mathrm{F}(3337)=7.64 * * * \\
p \text {-value }=0.0001\end{array}$ & $\begin{array}{c}\mathrm{F}(5335)=19.89 * * * \\
p \text {-value }<0.0001\end{array}$ & $\begin{array}{c}\mathrm{F}(7333)=14.32^{* * *} \\
p \text {-value }<0.0001\end{array}$ \\
\hline
\end{tabular}

Notes: For Independent variables and Constant rows the first number represents the estimated coefficient (the linear models were estimated by OLS), which is bolded for independent variables if the variable is statistically significant ${ }^{*}$ statistically significant at $10 \%, * *$ statistically significant at $5 \%, * * *$ statistically significant at $1 \%$ ), the second number shown in parentheses represents the Huber/White robust standard error, the third number represents the $p$-value, $\mathrm{n}$ is the number of observations, $\mathrm{R}^{2}$ is the coefficient of determination, $\mathrm{F}$ is the value of statistics $\mathrm{F}$ (below is the $p$-value). 
In a complimentary discussion, we reconcile the expected and observed signs of independent variables (Table 6).

Table 6. Reconciliation of expected and observed signs of independent variables.

\begin{tabular}{|c|c|c|c|c|}
\hline Variable & Expected Sign & Observed Sign & $\begin{array}{l}\text { Statistical } \\
\text { Significance }\end{array}$ & Discussion \\
\hline Gender & - & - & Yes & $\begin{array}{l}\text { We confirm that female students earn } \\
\text { higher GPAs than male students. }\end{array}$ \\
\hline Small Town & - & + & Yes & $\begin{array}{l}\text { We do not confirm that students who } \\
\text { completed secondary education in a } \\
\text { town with less than } 100,000 \\
\text { inhabitants earn lower GPAs than } \\
\text { other students. One of the plausible } \\
\text { explanations for this puzzle is that } \\
\text { such students perceive university } \\
\text { performance as the key to successful } \\
\text { career in a metropolis (in Poland } \\
\text { biggest universities are located in } \\
\text { large cities). }\end{array}$ \\
\hline Experience & - & - & Yes & $\begin{array}{l}\text { We confirm that students who have } \\
\text { professional experience earn lower } \\
\text { GPAs than students who do not have } \\
\text { professional experience. Assuming } \\
\text { students work (or worked), it is } \\
\text { reasonable to expect that they have } \\
\text { (or had) less time for studying. }\end{array}$ \\
\hline Full Time & + & + & Yes & $\begin{array}{l}\text { We confirm that full-time students } \\
\text { earn higher GPAs than part-time } \\
\text { students. Full-time students have } \\
\text { more time to study (assuming } \\
\text { part-time students work) and have } \\
\text { more in-class hours for every subject. } \\
\text { The former enables them to spread } \\
\text { the learning process over a longer } \\
\text { period. The latter enables them to } \\
\text { practice more during classes and ask } \\
\text { more questions (instructors may } \\
\text { clarify the material). }\end{array}$ \\
\hline Master's & + & + & Yes & $\begin{array}{l}\text { We confirm that master's students } \\
\text { earn higher GPAs than bachelor's } \\
\text { students. Master's students are more } \\
\text { matured than bachelor's students. } \\
\text { Graduate students value GPA and } \\
\text { expect to get a well-paid job, whereas } \\
\text { bachelor's students still have a chance } \\
\text { to enroll in master's studies and boost } \\
\text { their GPAs. }\end{array}$ \\
\hline Prof Qual & + & + & No & $\begin{array}{l}\text { The observed sign is as expected, but } \\
\text { the parameter is not statistically } \\
\text { significant at a conventional } \\
\text { significance level. }\end{array}$ \\
\hline Lang Cert & + & - & No & $\begin{array}{l}\text { The observed sign is contrary to } \\
\text { expectations, but the parameter is not } \\
\text { statistically significant at a } \\
\text { conventional significance level. }\end{array}$ \\
\hline
\end{tabular}

\section{Conclusions, Limitations, and Guidance for Further Studies}

A sustainable approach to education is realized by investing in pupils and students (i.e., financing their education) and expecting that next generations do at least the same. These well-educated members of society will not only move civilization forward, but also take care of previous generations and raise subsequent generations. It is of utmost importance to ensure equal access to education for all members of society. A society that finances tertiary education may expect that students gain knowledge, skills, and competences and become successful graduates who contribute their work to the 
nation. Our research contributes to the scientific debate through the identification and measurement of determinants of students' GPAs in a unique country setting, where top tertiary education is financed by the government.

We verified three research hypotheses, according to which students' performance was related to gender, location of secondary school (i.e., size of the city where secondary school was located), and work experience. The survey of 341 accounting and controlling students at Cracow University of Economics proved that in the unique country setting of a publicly financed system of higher education, female students earn higher GPAs than male students (research hypothesis H1). It suggests that men do not seize the chances offered by society to gain knowledge, skills, and competences in the same way as women. Further research in this area should focus on identifying detailed drivers of students' choices in this matter.

The research findings do not support the second hypothesis (research hypothesis H2)—students who graduated from secondary school in a large town earn lower GPAs than other students-which is contrary to initial predictions. It can be perceived as a puzzle, as this group of students has better access to education while at secondary school.

The outcome of the research confirms that the GPA of students with professional experience is statistically significantly lower than that of students without professional experience (research hypothesis H3). Regardless of the reasons for this phenomenon, the results of the study may be useful for higher education policymakers. The introduction of an incentives system that discourages students from taking up employment would facilitate a sustainable approach to education in a country in which education is financed by society. In such a setting, society pays for the education of young people to ensure sustainable development, which is based on new, highly educated generations. Therefore, the funds invested in future graduates should be used effectively. However, it requires further research, as the trade-off between GPA and professional experience is not a straightforward issue.

There were a number of limitations related to this study. The first one is the use of GPA as a proxy for academic achievements, and it is not the perfect measure of the total added value from education-compare with [25] (p. 879). The second one is the single-university analysis. Moreover, there was no possibility to confront obtained findings with personal features of students such as their intellectual potential.

Considering the aforementioned limitations of the study, we lay down guidance for further studies in the area of students' academic achievements. One area of future research should concentrate on re-running all analyses in a sample of universities of economics. That would allow researchers to control for specific environments in which respondents study. Another area of future research should concentrate on explaining earned GPA with additional factors such as intrinsic motivation and personal traits of students-compare the study by Kuśnierz et al. [42]. Last but not least, it would be valuable to identify and measure the benefits and drawbacks of taking up additional employment during studies. Following the careers of graduates would bring researchers to insightful conclusions. It could be an interesting path of research on sustainable approaches to education.

Author Contributions: Conceptualization, B.K. and I.G.; Data curation, B.K. and I.G.; Formal analysis, B.K. and I.G.; Funding acquisition, B.K. and I.G.; Investigation, B.K. and I.G.; Methodology, B.K. and I.G.; Project administration, B.K. and I.G.; Software, B.K.; Supervision, B.K.; Visualization, B.K.; Writing-original draft, B.K. and I.G.; Writing-review and editing, B.K. and I.G. All authors have read and agreed to the published version of the manuscript.

Funding: The publication was financed from the subsidy granted to the Cracow University of Economics.

Conflicts of Interest: The authors declare no conflict of interest. The funders had no role in the design of the study; in the collection, analyses, or interpretation of data; in the writing of the manuscript; or in the decision to publish the results. 


\section{References}

1. Semin, F.K. Competencies of Principals in Ensuring Sustainable Education: Teachers' Views. Int. J. Eval. Res. Educ. 2019, 8, 201-212.

2. Betts, J.R.; Morrell, D. The determinants of undergraduate grade point average. J. Hum. Resour. 1999, 34, 268-293. [CrossRef]

3. Cuadrado, D.; Salgado, J.F.; Moscoso, S. Prevalence and Correlates of Academic Dishonesty. Towards a Sustainable University. Sustainability 2019, 11, 6062. [CrossRef]

4. Filer, R.K. Sexual Differences in Earnings: The Role of Individual Personalities and Tastes. J. Hum. Resour. 1983, 18, 82. [CrossRef]

5. Jones, E.B.; Jackson, J.D. College grades and labor market rewards. J. Hum. Resour. 1990, 25, $253-266$. [CrossRef]

6. Rudakov, V.; Roshchin, S. The impact of student academic achievement on graduate salaries: The case of a leading Russian university. J. Educ. Work 2019, 32, 156-180. [CrossRef]

7. Wise, D.A. Academic achievement and job performance. Am. Econ. Rev. 1975, 65, 350-366.

8. Roth, P.L.; BeVier, C.A.; Switzer, F.S., III; Schippmann, J.S. Meta-analyzing the relationship between grades and job performance. J. Appl. Psychol. 1996, 81, 548-556. [CrossRef]

9. Oehrlein, P. Determining Future Success of College Students. Undergrad. Econ. Rev. 2009, 5, 7.

10. Spinath, B.; Eckert, C.; Steinmayr, R. Gender differences in school success: What are the roles of students' intelligence, personality and motivation? Educ. Res. 2014, 56, 230-243. [CrossRef]

11. Duckworth, A.L.; Seligman, M. Self-discipline gives girls the edge: Gender in self-discipline, grades, and achievement test scores. J. Educ. Psychol. 2006, 98, 198. [CrossRef]

12. Workman, J.; Heyder, A. Gender achievement gaps: The role of social costs to trying hard in high school. Soc. Psychol. Educ. 2020. [CrossRef]

13. Lewin, T. At Colleges, Women are Leaving Men in the Dust. The New York Times [Online]. 9 July 2006. Available online: https:/www.nytimes.com/2006/07/09/education/09college.html (accessed on 20 April 2020).

14. Bridgeman, B.; Wendler, C. Gender differences in predictors of college mathematics performance and in college mathematics course grades. J. Educ. Psychol. 1991, 83, 275-284. [CrossRef]

15. Conger, D.; Long, M.C. Why Are Men Falling Behind? Gender Gaps in College Performance and Persistence. Ann. Am. Acad. Political Soc. Sci. 2010, 627, 184-214. [CrossRef]

16. Claire, C.; McNeish, S.; McColl, J. The impact of part time employment on students' health and academic performance: A Scottish perspective. J. Furth. High. Educ. 2005, 29, 307-319.

17. Kusum, S. Part-Time Employment in High School and Its Effect on Academic Achievement. J. Educ. Res. 1998, 91, 131-139.

18. Tessema, M.T.; Ready, K.J.; Astani, M. Does part-time job affect college students' satisfaction and academic performance (GPA)? The case of a mid-sized public university. Int. J. Bus. Adm. 2014, 5, 50. [CrossRef]

19. Butler, A. Job Characteristics and College Performance and Attitudes: A Model of Work-School Conflict and Facilitation. J. Appl. Psychol. 2007, 92, 500-510. [CrossRef]

20. Cinamon, R.G. Integrating work and study among young adults: Testing and empirical model. J. Career Assess. 2016, 24, 527-542. [CrossRef]

21. Creed, P.A.; French, J.; Hood, M. Working while studying at university: The relationship between work benefits and demands and engagement and well-being. J. Vocat. Behav. 2015, 86, 48-57. [CrossRef]

22. Genett, A. The Effect of Paid Work on Academic Performance Amongst UNH Undergraduate Students. Perspectives 2017, 9, 7 .

23. Kalenkoski, C.; Pabilonia, S. Parental transfers, student achievement, and the labor supply of college students. J. Popul. Econ. 2010, 23, 469-496. [CrossRef]

24. Manthei, R.J.; Gilmore, A. The effect of paid employment on university students' lives. Educ. Train. 2005, 47, 202-215. [CrossRef]

25. Richardson, J.J.; Kemp, S.; Malinen, S.; Haultain, S.A. The academic achievement of students in a New Zealand university: Does it pay to work? J. Furth. High. Educ. 2013, 37, 864-882. [CrossRef]

26. Thibodeaux, J.; Deutsch, A.; Kitsantas, A.; Winsler, A. First-year college students' time use: Relations with self-regulation and GPA. J. Adv. Acad. 2017, 28, 5-27. [CrossRef] 
27. Coffey, B.K.; Barkley, A.; Tonsor, G.T.; Tack, J.B. How Do Students Allocate Their Time? An Application of Prospect Theory to Trade-offs between Time Spent to Improve GPA Versus Time Spent on Other Activities. Appl. Econ. Teach. Resour. 2020, 2, 1-14.

28. Spending on Tertiary Education (Indicator). Available online: https://data.oecd.org/eduresource/spendingon-tertiary-education.htm (accessed on 2 April 2020).

29. Education at a Glance, Poland. Available online: https://www.oecd.org/education/education-at-a-glance/ EAG2019_CN_POL.pdf (accessed on 2 April 2020).

30. Kabalski, P.; Szwajcar, J. Feminizacja studiów w zakresie rachunkowości w Polsce-przyczyny i skutki. Zesz. Teor. Rachun. 2015, 81, 85-106. [CrossRef]

31. Masztalerz, M. Czy Rachunkowość w Polsce Jest Kobietą? Prace Nauk. Uniw. Ekon. We Wrocławiu 2018, 503, 326-335. [CrossRef]

32. Wieczorek-Szymańska, A. Gender Diversity in Academic Sector-Case Study. Adm. Sci. 2020, $10,41$. [CrossRef]

33. Informacja o Wynikach Rekrutacji na Studia na Rok Akademicki 2019/2020 w Uczelniach Nadzorowanych Przez Ministra Nauki i Szkolnictwa Wyższego. Available online: https://www.gov.pl/attachment/206732e6ae69-4d5b-b6cc-151c8cefb1c8 (accessed on 2 April 2020).

34. Zarzycka, E.; Dobroszek, J. Education in the area of management accounting/controlling in Poland and Germany. Soc. Sci. 2015, 87, 74-88. [CrossRef]

35. Barometr Zawodów 2019, Wojewódzki Urząd Pracy w Krakowie, Kraków 2018. Available online: https: //barometrzawodow.pl/userfiles/Barometr/2019/raport_ogolnopolski_pl.pdf (accessed on 2 April 2020).

36. Świerzbowska-Kowalik, E. Wykształcenie środowisk rodzinnych i miejsce zamieszkania jako wyznaczniki szans na podjęcie studiów. Nauka Szk. Wyższe 2000, 16, 108-135.

37. Ostoj, I. Motywy podejmowania pracy przez studentów studiów stacjonarnych—Wyniki badań. Studia Prace WNEiZ US 2016, 44, 231-241. [CrossRef]

38. Ranking Liceów Ogólnokształcących 2019, Perspektywy. Available online: http://licea.perspektywy.pl/2019/ ranking/ranking-liceow-ogolnoksztalcacych-2019 (accessed on 2 April 2020).

39. Business Services Sector in Poland 2019. Available online: https://absl.pl/storage/app/uploads/public/5d0/ 7a1/406/5d07a140668f0191663458.pdf (accessed on 10 April 2020).

40. Tholons Services Globalization Index 2019, Innovation at Scale, Digital Nations \& Super Cites. Available online: http://www.tholons.com/Tholonstop100/TSGI2019Report.pdf (accessed on 5 April 2020).

41. Łada, M.; Konieczny, A. Specjalista czy "wstukiwacz"-Postrzeganie zatrudnienia w centrum usług finansowo-księgowych. Studia Ekon. 2015, 225, 102-112.

42. Kuśnierz, C.; Rogowska, A.M.; Pavlova, I. Examining Gender Differences, Personality Traits, Academic Performance, and Motivation in Ukrainian and Polish Students of Physical Education: A Cross-Cultural Study. Int. J. Environ. Res. Public Health 2020, 17, 5729. [CrossRef]

Publisher's Note: MDPI stays neutral with regard to jurisdictional claims in published maps and institutional affiliations.

(C) 2020 by the authors. Licensee MDPI, Basel, Switzerland. This article is an open access article distributed under the terms and conditions of the Creative Commons Attribution (CC BY) license (http://creativecommons.org/licenses/by/4.0/). 